\title{
The differential impact of employment in agriculture on wages for rural and non- rural Palestine
}

\author{
Yousef Daoud $^{1,2^{*}}$ (D) and Belal Fallah ${ }^{3}$
}

\author{
* Correspondence: \\ Yousef.Daoud@dohainstitute.edu.qa \\ ${ }^{1}$ Doha Institute for Graduate \\ Studies, Al Tarfa Street, Zone 70, PO \\ Box 200592, Al-Daayen, Qatar \\ 2Department of Economics, College \\ of Business and Economics, Birzeit \\ University, P O Box 14, Birzeit, \\ Palestine \\ Full list of author information is \\ available at the end of the article
}

\begin{abstract}
This paper investigates the differential impact of employment in agriculture on rural and non-rural wages using the quarterly labor force survey (LFS) collected by the Palestine Central Bureau of Statistics (PCBS). We estimate the wage equation for rural and non-rural workers controlling for structural, socioeconomic, and political factors. The results suggest that employment in agriculture lowers the average wage by a range from 26 to $34 \%$ for the non-rural population and 30-37\% for rural population. Meanwhile, Israeli closures tend to raise the probability of selecting agriculture as a sector for employment. Among other findings, the results also show that returns to education are lower for rural workers than for non-rural workers.

JEL Classification: R11, J30, J61, J01
\end{abstract}

Keywords: Labor supply, Labor demand, Commuting, Wage differential

\section{Introduction}

The Palestinian labor market has experienced considerable attention from researchers from within and outside the region for two reasons. The first is the release of raw data from the Palestine Central Bureau of Statistics (PCBS) at the turn of the century of the quarterly labor force survey, and the second is due to the conflict with Israel and the lack of progress in the peace process. Although Palestine is geographically a small area, it is far from being contiguous. Settlements and security zones inhibit rural urban migration, and as a result, we notice higher migration in the Gaza Strip than in the West Bank because Gaza is free of settlements (despite the blockade). Another unique feature of the Palestinian labor markets is the proximity to the Israeli labor market and the frequent interruptions to labor flows; this has considerable negative shocks to rural Palestine (mainly the West Bank as Gaza is blockaded). The vulnerability of the Palestinian rural population is compounded by a disproportionate share of employment in agriculture. In general, it is argued that rural wages are lower (among other things) because of the lower stock of human capital in rural Palestine. We argue that the disproportionate share of employment in agriculture coupled with higher share of employment in Israel is potentially contributing to the lower stock of human capital in rural areas. To improve the well-being of Palestinian rural areas, it is imperative to understand the dynamics of employment in agriculture and its effect on wages.

(c) The Author(s). 2016 Open Access This article is distributed under the terms of the Creative Commons Attribution 4.0 International License (http://creativecommons.org/licenses/by/4.0/), which permits unrestricted use, distribution, and reproduction in any medium, provided you give appropriate credit to the original author(s) and the source, provide a link to the Creative Commons license, and indicate if changes were made. 
The literature on wage gaps in labor economics cites three types of gaps: a gender wage gap in favor of males, an urban rural wage gap in favor of urban areas, and a sector wage gap in favor of non-agricultural jobs vis-à-vis agricultural jobs. The magnitude of such gaps varies with country and estimation technique. Hertz et al. (2008) provide estimates for the unexplained portion of the gap which can reach at least $30 \%$ for the farm/non-farm wage employees and rise to $56 \%$ in some cases. Their contention is that the urban-rural wage gap is higher where the probability of getting a job in urban centers remains low. Although early models of development conflated the terms rural and agricultural employment, the distinction has become more important in recent years. Winters et al. (2008) investigate whether wage employment in agriculture has potential in improving the well-being of rural areas for 14 countries. They find that investment in education and infrastructure are far more important for finding high-paying jobs than for choosing a particular sector. This distinction implies that the traditional view of rural workers having only the option to migrate because of the higher expected wage and greater probability of getting a job in the urban centers is no longer the only viable solution to rural workers. Rather, individuals have a choice in finding non-agricultural jobs in the rural areas.

Gollin et al. (2014) applied improved measurements of inputs (human capital and hours worked) and outputs to find out that a sizable productivity gap still exists in agriculture. This suggests that moving workers out of agriculture shall improve productivity in agriculture and reduce the inefficiency of resource misallocation. In an earlier paper, Lagakos and Waugh (2009) argue that subsistence food requirements motivate low-productivity workers to self-select into agriculture. On the other hand, the urban/ rural wage gap is partly shown to depend on spatial mobility (Lagakos et al. 2016) arguing that sorting and migration cost explain the spatial wage gap.

In a recent article, Fallah and Daoud (2015) investigate the impact of restrictions imposed by the occupation authorities on area $C$, which falls directly under Israeli security jurisdiction, on wages; they find that there is an $8 \%$ gap between area $\mathrm{C}$ and the other areas. ${ }^{1}$ The restrictions include an almost complete ban on construction as well as limits on the movement of labor and goods among other measures. Area $\mathrm{C}$ is mostly rural; thus, one would expect lower wages resulting from the restrained labor demand. Their findings reveal a $13 \%$ wage gap between rural and urban residents and that the area $\mathrm{C}$ gap is not mainly driven by Israeli restrictions, but rather "a rural character effect." Prior to that, Daoud (2005) showed a much lower gap using 1999 and 2001 data. Depending on specification, the 1999 data showed that average wages in rural areas enjoyed a 1-2 \% premium over urban dwellers. This gap turned negative (around $-3 \%$ ) in 2001 with a higher negative impact for rural females over males. In addition, the closure of Israeli labor markets led to higher unemployment and lower wages.

Our paper complements the literature in that it explores the role of employment in agriculture in the determination of wages for rural and non-rural workers. None of the reviewed works addresses this issue directly. ${ }^{2}$ Therefore, the contribution of our paper is twofold: first, we find evidence that employment in agriculture has a bigger negative effect on wages for rural residents, and second, it is the first to apply the selection in agriculture in Palestine. The implications of these findings suggest that there is a stronger case for reallocating workers out of agriculture in rural Palestine. It is also evident that the Israeli labor market cannot be relied upon as a source of higher wages and 
employment in the long run as it may be responsible for the lower return to education particularly in rural areas.

The present study is the first to consider rural labor market and self-selection into agriculture in Palestine. It shows the average daily wage distributions for rural and non-rural areas in the years 1999 and 2012. Figure 1 below suggests that the distributions are closer in 2012 compared to 1999 and a slight improvement for rural wages. ${ }^{3}$ By controlling for migration (to the Israeli labor market), education, occupation, and other worker and industry characteristics, we aim to estimate the effect of employment in the agricultural sector on the rural and non-rural population and find out which factors affect the decision to select into agriculture.

While the Israeli labor market has been shrinking its dependency on Palestinian workers since 1993 and more severely since $2000,{ }^{4}$ the Palestinian Authority (PA) has been opening opportunities for skilled workers in the public sector. ${ }^{5}$ As a result, many rural workers ended up with government jobs, meanwhile taking part in casual agricultural work (Sayre 2001). The PA followed a policy of support to the agricultural sector to increase the resilience of the rural work force and to avoid land confiscation by Israel for settlement activities. However, employment in agriculture in rural Palestine is similar to many other developing countries in that it is seasonal, but it differs because it acts as a refuge for workers whose employment is disrupted due to political unrest. The rural population makes up $17 \%$ of the total Palestinian population, which accounts for almost three quarters of a million people, thus making the impact of political as well as structural factors on wages and reallocation a large one.

Our hypothesis is that the sector of employment matters significantly for rural wages. In particular, the rural population relies heavily on agriculture for employment and that may be responsible for the rural-non-rural wage gap. As the economy grows, reliance on agriculture as a sector of employment diminishes overtime; hence, one would expect a convergence of wages in the two areas (Hnatkovska and Lahiri 2013). Rural areas also depend more heavily on employment in Israel (where wages are higher), but the importance of this source of disparity has been diminishing overtime due to restriction on labor mobility by Israel. This may favor the wage convergence hypothesis which states

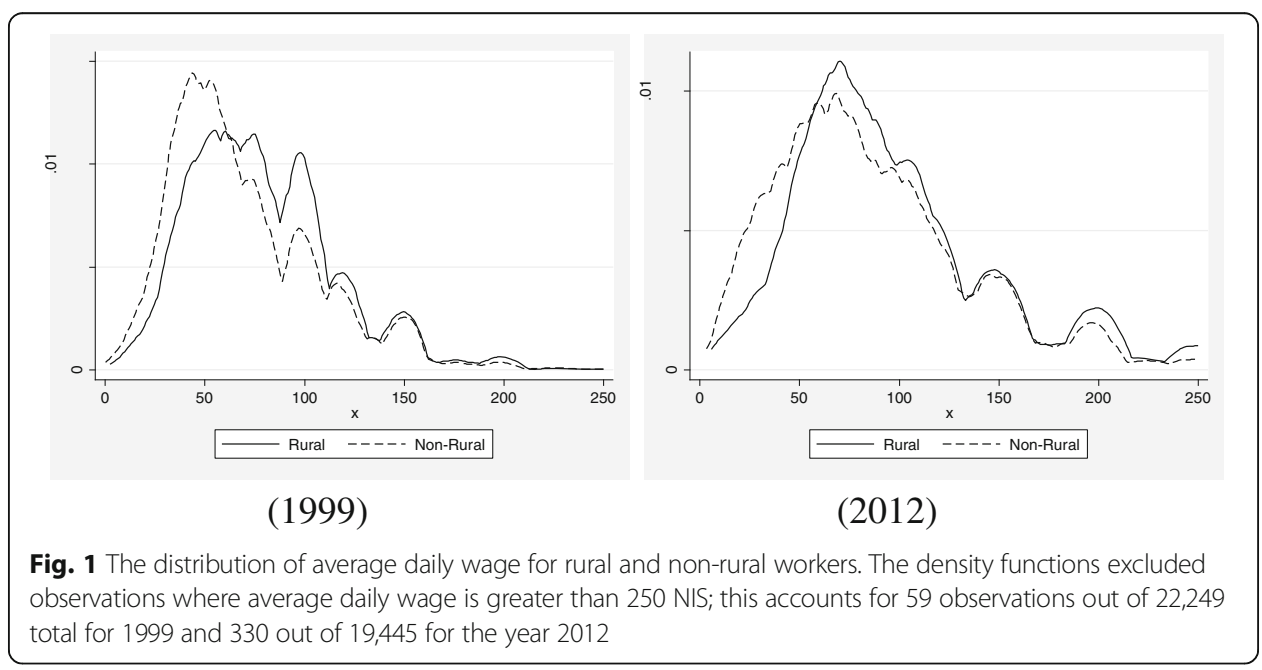


that rural and non-rural wages will tend to converge as the agricultural share of employment gets smaller and access to the Israeli labor market becomes more restricted.

The paper is organized as follows: the next section presents a review of the relevant literature; the data and descriptive analysis that motivate the model are presented next. Section 4 explains the econometric methodology, followed by the empirical findings. Finally, Section 6 concludes and provides policy recommendations.

\section{Literature review}

Recent studies focusing on migration report that urban-rural wage gap represents a spatial misallocation of labor and is the motivating factor for urban bound migration. Munshi and Rosenzweig (2016) report that the net gains from migration are still positive and large even after adjusting for purchasing power parity (PPP) and weighing the data by the probability of unemployment and underemployment. ${ }^{6}$ Lagakos et al. (2016) echo similar findings in that the urban rural wage gap results primarily from sorting, disutility from migration, and migration risk. Evidence on the sorting hypothesis for Middle Eastern countries was addressed by McCormick and Wahba (2005) who found evidence that the supply side is responsible at least in part for the concentration of the skilled workers in big cities.

Stiglitz (1974) provided a model of labor turnover as a reason why firms in urban centers pay a higher wage than in the rural sector. In his model, monitoring and training are the driving forces behind a rural-urban wage gap despite the widespread unemployment in less developing countries. Recent studies point to the agglomeration effect (Combes et al. 2008) in enhancing worker productivity from being in urban centers where most of the jobs are located. The sorting effect is another mechanism through which urban wages can be higher than rural wages due to lower job search cost of better job offers (Kim 1990).

The literature on wage setting in rural agriculture postulates that there are some individuals who are satisfied with a subsistence ${ }^{7}$ level of consumption; thus, the less productive ones select into agriculture in an economy where overall efficiency is low. Developed economies, on the other hand, are more efficient; thus, the few that select into agriculture must be more productive than the average. This, according to Lagakos and Waugh (2013), results into larger differences in agricultural productivity between developed and less developing countries. ${ }^{8}$ Another breed of papers distinguishes between the types of wage contracts. Moretti and Perloff (2002) use the efficiency wage model to explain wage differential in agriculture in California. They distinguish between two types of payments: the first is the direct hire model, and the second is through local labor contractors. The first group gets higher wages as a mechanism to reduce monitoring cost and shirking. They test the efficiency wage model against alternative models and find evidence that the efficiency wage model outperforms the human capital model, the dual labor market model, and insurance model.

Ahmad (1982) uses the labor supply-demand framework to address the question as to why widespread unemployment and underemployment in developing countries would not depress wages in agriculture. He distinguishes between voluntary and involuntary unemployment. The increased labor supply of the involuntarily unemployed casual worker is very small (relative to total unemployment) to depress wages. His contention is that the surplus labor model of Lewis (1954) and the efficiency wage 
model of Leibenstein (1957) and Bliss and Stern (1976) are not sufficient to explain wage behavior. The reason is that the subsistence wage model necessitates a wage level enough to perpetuate the population; therefore, in a country with an increasing population, wages must be higher than the subsistence level (Ahmad 1982). On the other hand, the efficiency wage model requires a certain caloric intake which Bliss and Stern (1976) found is less than what is needed to support the efficiency wage. Both of these theories alone cannot explain wages in agricultural Bangladesh. Ahmad (1982) postulates that structural factors such as inequality in land distribution, cropping intensity, and tenancy positively affect wages, while the proportion of agricultural wage laborers and uncertainty in production affect wages negatively. ${ }^{9}$

The literature on rural and agricultural wages in the occupied Palestinian territory (oPt) is less frequent. Many studies have recently focused on the wages of Palestinian workers in general. The focus was prompted by Angrist's studies (1995, 1996, and 1998) of returns to education and employment in Israel. ${ }^{10}$ Angrist (1995) finds declining returns to education due to increased supply of university graduates. Daoud (2005) finds low returns to education, but at the margin, returns to female education are higher. The analysis in Daoud (2005) reveals that closures ${ }^{11}$ have a differential impact on males and females' unemployment; the ratio of male to female unemployment increased from 1.4 in 1999 to 3.5 in the Intifada year 2001. Daoud and Shanti (2012) investigated employment sector choice and wage differential and find that education has a more profound effect on female participation in all sectors. They also find that male wages are higher in the public sector than in the private sector but that the gap is mostly explainable by the endowment effect. On the other hand, the male/female wage gap in the private sector is not mostly explained by endowments; rather, it is unexplained for the most part. Sayre (2001) utilized the same data used by Angrist (1995) to compare the wage premium due to schooling between 1981 and 2001. In another study, Sayre and Miller (2004) examined the relationship between labor demand shocks and the reversal of returns to education in Palestine; they argue that the establishment of the PA increased the demand for skilled workers leading to an increase in the wages of skilled workers relative to the unskilled wages. Hazan and Zoabi (2011) treat the wage issue from a different perspective, looking at fertility issues and parental preference for boys rather than girls in an attempt to explain the higher female returns. Mansour (2010) shows that employment restrictions on Palestinians employed in Israel constitute a negative labor supply shock leading to an increase in the schooling return. Miaari (2009) uses quantile regression to decompose wage differential for private/public sector. Tansel and Daoud (2011) provide a comparative analysis of returns to education on Palestine and Turkey. Daoud and Sadeq (2012) investigate the determinants of returns to education using quarterly labor force survey data covering 1996-2011.

The emphasis in the previous literature is on returns to education with public-private sector selection correction or gender self-selection. The rural sector is introduced simply as a dummy variable to check whether rural sector wages are higher or lower than urban and camp dwellers.

\section{Data and sample descriptive statistics}

This section provides an overview of some Palestinian labor market regularities relating to rural and non-rural employment patterns. The structural distribution of wage 
employment, schooling, and employment in Israel are thought to have strong and varying effect on rural and non-rural wages. We first focus our attention on wage distributions for rural and non-rural Palestine. Our data comes from the PCBS household labor force survey data covering the period starting with the first quarter of 1999 to quarter four of $2012 .{ }^{12}$ The frequency of the data is quarterly; each household is interviewed twice successively-dropped from the sample for two quarters, and then reinterviewed for another two quarters. The average daily wage is reported in New Israeli Shekel (NIS). Figure 1 below gives an overall description of rural and non-rural wage densities.

The wage density in Fig. 1 shows that in 2012, rural wages have a higher peak which is the opposite of 1999 but that the two distributions are closer together in 2012 implying that the wage gap is getting narrower. The forces at work that may be responsible for this convergence phenomenon are structural transformation factors (distribution of employment by industry), human capital factors (education, experience, and other socioeconomic factors), supply and demand shocks resulting from political unrest (2006 and 2001 dummies), migration, and employment in Israel. For example, if more workers from non-rural areas work in Israel (where wages are higher), and access to the Israeli labor market is becoming more restricted, then we expect non-rural wages to fall on average, thus getting closer to wages in rural areas. Alternatively, an increased demand in the public sector would tend to draw workers from agriculture to public service, thus raising wages for agricultural rural workers. Figure 5 below shows that average years of schooling for rural residents has been catching up with non-rural schooling which tend to narrow the gap.

The structural transformation hypothesis postulates that (Caselli and Coleman 2001; Hnatkovska and Lahiri 2013) increases in agricultural productivity release workers from agriculture and increase the supply of labor to urban centers (migration) lowering the urban workers' relative wage. Our data suggests that the share of rural employment in agriculture tends to fluctuate with a declining trend reaching $38.6 \%$ in the fourth quarter of 2006 and a low $17.4 \%$ in the third quarter of $2010 .{ }^{13}$ However, during the same period, this proportion stays around $10 \%$ for non-rural areas. The distribution of employment by industry averaged over the entire sample period is given below (Fig. 2).

The share of employment in other services, which is mainly from the public sector, is highest for both rural and non-rural workers; it is however one and a half times larger for non-rural workers. The opposite is true for the construction sector; the proportion of rural employment in construction is almost double that for non-rural workers.

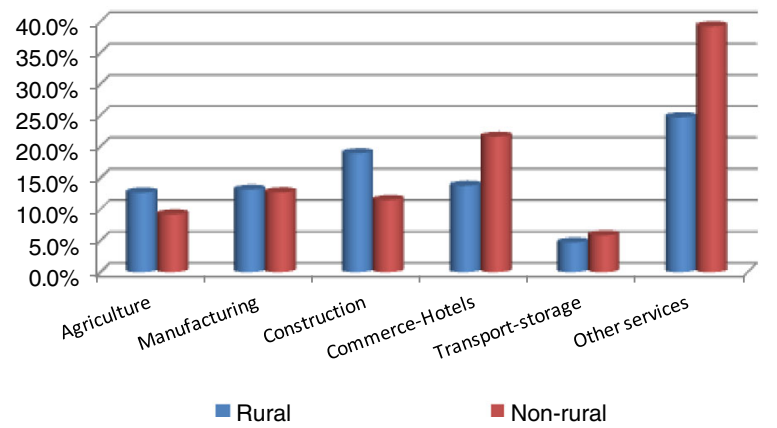

Fig. 2 Employment distribution by industry and type of locality 
Agriculture's share of rural employment is roughly $12 \%$ in rural areas, while it is only $8 \%$ for non-rural workers. These differences are likely to have an impact on the wages of workers in both areas, as well as on migration. The migration data shows that for the oPt as a whole, the proportion of workers who work in the same district of residence fluctuates around $60 \%$ for the West Bank and $20 \%$ for Gaza. This implies that the proportion that migrates (which includes another district, Israel, and international locations) is much higher in Gaza Strip. Thus, fewer people migrate to other districts and other locations in the West Bank. ${ }^{14}$ This may be a reflection of lower wage gap between rural and non-rural areas, or that movement restrictions are the reason. Yashiv (2008) uses Israel Central Bureau of Statistics on Palestinian workers in Israel; he finds that migrants are less skilled than stayers. The results also indicate that a high migration premium attracts migrants but that skilled workers will get a low return (offered low skill jobs) and are thus deterred.

For the rural population (and the urban population as well), employment in Israel and the settlements is the location of choice because wages are higher. The proportion of total employment in Israel is higher for rural areas than it is in non-rural areas, which tends to raise rural wages above those in non-rural areas.

The human capital model, Mincer (1974) and Becker (1964), relates wages to years of schooling, experience, and quadratic experience to account for concavity in the earnings profile. Figure 3 below shows a time series plot of quarterly average years of schooling versus average daily wage for rural and non-rural workers. The evidence shows that while schooling is higher on average for non-rural workers, their wages tend to be occasionally lower.

Between 2000 and 2010, the average daily wage series for rural and non-rural are practically indistinguishable from each other, while the schooling gap is wide and is not changing drastically. Meanwhile, the schooling gap is narrowing after 2009, while the wage gap is widening. This suggests that employment in Israel may be the reason behind this divergence in wages (see Fig. 4).

Figure 4 provides a time series plot of average years of schooling and proportion of employment in Israel for rural and non-rural areas for each quarter. This plot illustrates the extent to which wage differentials depend on differences in employment shares. It is clear that since the outbreak of the second Intifada (fourth quarter of 2000), the proportion of rural employment in Israel dropped from $30 \%$ to almost $7 \%$ and nearly equal to the proportion for non-rural workers. The wage differential was nearly zero

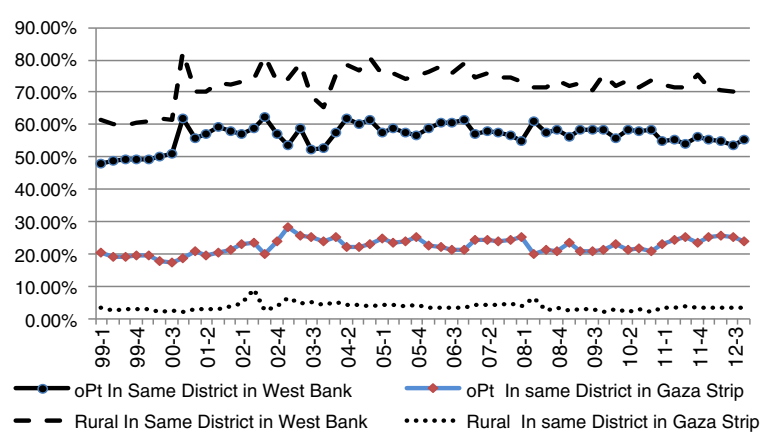

Fig. 3 Proportion of workers who work and reside in the same district 


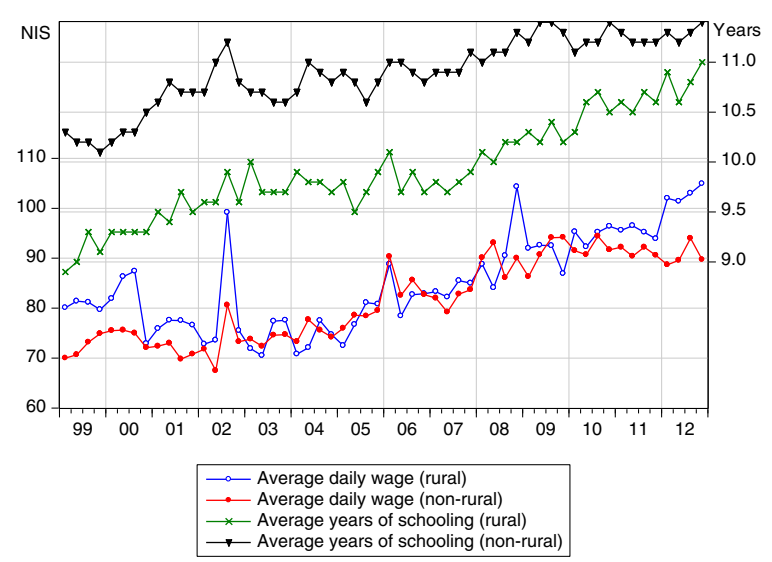

Fig. 4 Schooling and wages for rural and non-rural workers

for that period. Also, for the year 2012, the gap in employment shares is very wide, so is the wage gap. The data also suggests that rural wages are more volatile and seem to have a positive covariance with employment in Israel (Fig. 5).

The years 2000, 2009, and 2012 highlight the positive association between share of employment in Israel for rural residents and rural wages. Regression analyses in subsequent sections show that employment in Israel has a large wage premium despite the lower schooling for such workers (i.e., lower returns to schooling).

\section{Model}

The sample descriptive statistics in the preceding section suggest some factors which could be responsible for the differential impact on rural and non-rural wages. The inclusion of the vector of socioeconomic variables for each type of locality helps identify the differential impact. The empirical strategy to assess such differential impact is to estimate the Mincer earning equation (Mincer 1974) using PCBS labor force survey data that covers the 1999-2012 period. The worker's log average daily wage is a function of worker's demographic, educational attainment, and labor characteristics. ${ }^{15}$ The main variable of interest is the type of industry, which for the purpose of this study is

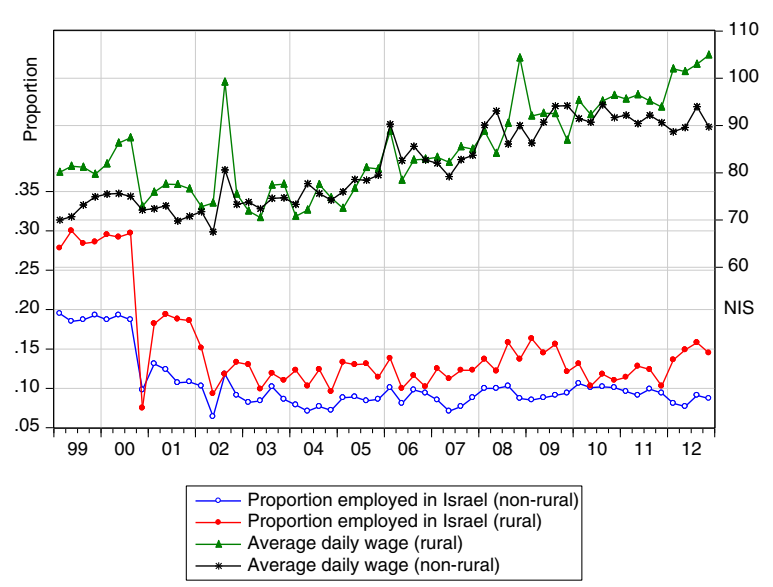

Fig. 5 Employment in Israel and wages 
classified into agricultural and non-agricultural sector. This industry classification is formed as an industry dummy variable that takes the value of 1 for the agricultural sector and 0 for other sectors. All else equal, the coefficient of industry classification estimates the wage differential between agriculture relative to other sectors (the reference group).

The above analysis is based on rural wage employment. Still, a considerable share of rural total employment is unpaid family workers (12\% in 2010). This is likely to create selectivity bias, which would produce a downward bias of the industry estimate. Maluccio (1998) shows that OLS estimates of returns to schooling are biased downward by as much as $60 \%$ if selection is ignored. We control for unpaid wage-selectivity bias by controlling for parent's type of industry. In particular, workers' and their parent's type of industry is the same. The rationale of using parent's type of industry is that it increases the probability of selecting the same business. ${ }^{16}$

Another source of selectivity bias ${ }^{17}$ is industry self-selection. That is, workers are not-necessarily randomly distributed across industries. We correct for this selectivity bias using Heckman's (1976) two-stage estimation model. The first-stage model is a Probit model in which the dependent variable $(D)$ is a binary variable, which takes 1 for workers employed in agriculture sector and 0 for those employed in non-agriculture sector. This dependent variable is regressed on worker's demographic characteristics $(X)$, education attainment, and type of industry. We also control for other variables that would affect worker's self-selection, including a dummy variable that indicates if a worker's type of industry is the same as his/her parent. This, as explained above, is used to control for unpaid wage employees.

\section{Empirical results}

Estimates of model are reported in Tables 1 and 2; we begin by the wage equation where self-selection is considered for people who are wage employees in agriculture. ${ }^{18}$ The equations are estimated for the two subpopulations, rural and non-rural populations. The motivation for this sample splitting regression is to check for observed differences in the wage determination for each area. Although we estimate the wage equation as a linear function of schooling at this stage, we do provide non-linear specifications in Tables 5 and 6 . The schooling coefficient is very low for both areas, ${ }^{19}$ and it indicates that a linear specification means an increase in schooling by 1 year leads to a $0.7 \%$ increase in average daily wage; the coefficient is significant for both areas (rural and non-rural). Regressions on a year by year basis yield estimates more in line with the ones reported in the literature. The earnings profile is evident by the sign of age and age square which are significant and have a positive and negative signs, respectively. ${ }^{20}$ Female earnings are $14.9 \%$ lower than their male counterparts in nonrural areas. This is compared with $12 \%$ in rural areas.

Controlling for workers' education, being employed in Israel results in a higher wage premium in non-rural areas; a non-rural worker would earn $59.2 \%$ more than a person with the same attributes that is employed domestically. Rural workers in Israel earn only $43.9 \%$ more than their domestically employed counterparts. Investigation of the wage distributions for rural and non-rural workers reveals that the wage distributions for those who work in Israel and the settlements are negatively skewed (left) for nonrural workers while it is positively skewed (right) for rural workers. In such cases, it is 
Table 1 Heckman joint maximum likelihood estimates of the wage equation

\begin{tabular}{|c|c|c|c|c|c|c|}
\hline & \multicolumn{3}{|c|}{ Non-rural population } & \multicolumn{3}{|c|}{ Rural population } \\
\hline & Coeff. & $\mathrm{Se}$ & $P$ value & Coeff. & Se & $P$ value \\
\hline Schooling & 0.0078 & 0.0019 & 0.0000 & 0.0069 & 0.0020 & 0.0010 \\
\hline Age & 0.0270 & 0.0032 & 0.0000 & 0.0281 & 0.0038 & 0.0000 \\
\hline Age square & -0.0003 & 0.0000 & 0.0000 & -0.0003 & 0.0000 & 0.0000 \\
\hline Female & -0.1493 & 0.0401 & 0.0000 & -0.1209 & 0.0316 & 0.0000 \\
\hline Work in Israel & 0.5928 & 0.0151 & 0.0000 & 0.4390 & 0.0147 & 0.0000 \\
\hline \multicolumn{7}{|l|}{ Occupation dummies $^{a}$} \\
\hline Legislators and senior administrators & 0.8794 & 0.4129 & 0.0330 & -0.1359 & 0.0506 & 0.0070 \\
\hline Professionals and clerks & 0.4532 & 0.1179 & 0.0000 & 0.4596 & 0.1139 & 0.0000 \\
\hline Services and shop sales & 0.1468 & 0.0863 & 0.0890 & -0.1190 & 0.1218 & 0.3290 \\
\hline Skilled agricultural and fishery workers & -0.0106 & 0.0236 & 0.6510 & 0.0820 & 0.0232 & 0.0000 \\
\hline Crafts' workers & 0.2197 & 0.1220 & 0.0720 & -0.0313 & 0.0976 & 0.7490 \\
\hline Plant and machine operators & 0.2561 & 0.0685 & 0.0000 & 0.2338 & 0.0733 & 0.0010 \\
\hline \multicolumn{7}{|l|}{ Governorate dummies $^{a}$} \\
\hline Jenin & 0.6312 & 0.0334 & 0.0000 & 0.5724 & 0.0331 & 0.0000 \\
\hline Tubas & 0.5664 & 0.0240 & 0.0000 & 0.3333 & 0.0325 & 0.0000 \\
\hline Tulkarem & 0.5428 & 0.0256 & 0.0000 & 0.4939 & 0.0376 & 0.0000 \\
\hline Nablus & 0.7052 & 0.0722 & 0.0000 & 0.4553 & 0.0420 & 0.0000 \\
\hline Qalqilia & 0.6708 & 0.0357 & 0.0000 & 0.6496 & 0.0409 & 0.0000 \\
\hline Salfeet & 0.8953 & 0.0785 & 0.0000 & 0.8024 & 0.0496 & 0.0000 \\
\hline Ramallah & 0.8628 & 0.0991 & 0.0000 & 0.6479 & 0.0412 & 0.0000 \\
\hline Jericho & 0.5522 & 0.0219 & 0.0000 & 0.3573 & 0.0303 & 0.0000 \\
\hline Jerusalem & 1.0478 & 0.0459 & 0.0000 & 0.8206 & 0.0555 & 0.0000 \\
\hline 41 & 1.0697 & 0.0464 & 0.0000 & & & \\
\hline Bethlahim & 0.7395 & 0.0630 & 0.0000 & 0.7379 & 0.0525 & 0.0000 \\
\hline Hebron & 0.6721 & 0.0307 & 0.0000 & 0.5415 & 0.0388 & 0.0000 \\
\hline GS-north & 0.2208 & 0.0247 & 0.0000 & 0.2184 & 0.0669 & 0.0010 \\
\hline Gaza city & 0.2416 & 0.0379 & 0.0000 & 0.1985 & 0.0443 & 0.0000 \\
\hline Deir Albalah & 0.0719 & 0.0258 & 0.0050 & 0.0440 & 0.0624 & 0.4810 \\
\hline Khan younis & -0.0364 & 0.0219 & 0.0960 & 0.0837 & 0.0350 & 0.0170 \\
\hline Constant & 2.6862 & 0.0790 & 0.0000 & 2.7360 & 0.0949 & 0.0000 \\
\hline
\end{tabular}

Quarter dummies are removed for brevity and can be made available at request

${ }^{a}$ The base groups for occupation dummies is elementary occupations, for quarter dummies is the third quarter of 2012 and for governorate is Rafah

better to use the median than the mean; the median wage ratio of rural to non-rural employed in Israel and the settlements is $85.7 \%$ while the same ratio is at parity in the domestic market. The distribution over occupations is very similar except that the proportion is a little higher for non-rural workers in services and shop sales; however, the bulk is in elementary occupations for both groups. We are unable to disentangle whether the place of work is in Israel or the settlements ${ }^{21}$ which may account for part of this disparity.

Because the selection equation is for employment in agriculture, we cannot include industry dummies. Instead, we use occupation categories in which elementary occupation is the base category. Of particular interest is the coefficient on skilled agricultural and fishery workers. Being a skilled agricultural worker implies no significant change in 
Table 2 Heckman Joint maximum likelihood estimates of the selection equation (robust standard errors)

\begin{tabular}{|c|c|c|c|c|c|c|}
\hline \multirow[t]{2}{*}{ Variable } & \multicolumn{3}{|c|}{ Non-rural population } & \multicolumn{3}{|l|}{ Rural } \\
\hline & Coeff. & $\mathrm{Se}$ & $P$ value & Coeff. & $\mathrm{Se}$ & $P$ value \\
\hline Household head works in agriculture & 10.078 & 0.036 & 0.000 & 9.201 & 0.065 & 0.000 \\
\hline Household size & 0.056 & 0.003 & 0.000 & 0.043 & 0.004 & 0.000 \\
\hline Total household wage income & -0.001 & 0.000 & 0.000 & -0.003 & 0.000 & 0.000 \\
\hline 2001 dummy & -0.046 & 0.050 & 0.360 & -0.101 & 0.057 & 0.079 \\
\hline 2006 dummy & -0.063 & 0.052 & 0.232 & 0.189 & 0.042 & 0.000 \\
\hline Never married & 0.609 & 0.033 & 0.000 & 0.751 & 0.037 & 0.000 \\
\hline Schooling & -0.045 & 0.003 & 0.000 & -0.038 & 0.003 & 0.000 \\
\hline Constant & -3.048 & 0.045 & 0.000 & -2.662 & 0.053 & 0.000 \\
\hline Rho & -0.017 & 0.019 & & -0.010 & 0.024 & \\
\hline Sigma & 0.381 & 0.005 & & 0.346 & 0.006 & \\
\hline Lambda & -0.006 & 0.007 & & -0.003 & 0.008 & \\
\hline $\mathrm{Chi}^{2}(1)$ & 0.760 & & 0.384 & 0.170 & & 0.679 \\
\hline
\end{tabular}

wages for non-rural population; however, having this occupation implies an increase by about $8 \%$ above the level of elementary occupations for the rural population. Professional clerks have the highest occupation premium in rural areas. The average daily wage for workers in services and shop sales are not significantly different from those in elementary occupations in rural areas.

Finally, workers in almost all governorates have higher wages than Rafah governorate (a depressed area in Gaza on the border with Egypt) with varying degrees. The geographic wage differential is often lower in rural areas, for example, Deir Albalah wages are practically the same as those in Rafah but Salfeet enjoys an $80 \%$ premium. In non-rural areas, the gap is as low as $-3.6 \%$ for Khan Younis and as high as $105 \%$ in Jerusalem's favor. West Bank and Gaza differences are evident from the coefficients on the last four governorate dummies (located in Gaza). Differences with Rafah are much lower in Gaza than in West Bank governorates.

On the question why do individuals select to work in agriculture, we find evidence suggesting that schooling and total household wage income reduce the probability of being employed in agriculture significantly (by 3.4 and $0.1 \%$, respectively). The differences in the magnitude for each of those variables are not large. The time dummies are included to show the effect of severe political closures on employment in agriculture; the 2006 dummy shows that for rural areas, the probability of selecting into agriculture increased and was significant and, for non-rural areas, it was not significant. This supports the view that more people turn to agriculture for employment when other market opportunities disappear. This confirms the employment consequences on rural and non-rural areas. Closures have a more serious impact on wages and unemployment for rural areas, thus giving agriculture special support and/or programs is important for the rural population. ${ }^{22}$ We also find that if the household head is employed in agriculture, the likelihood of selecting the agricultural sector increases dramatically. Larger households and never married ${ }^{23}$ are also more likely to select this sector.

Estimation with selection correction requires that the error terms from the first stage and second stage be correlated, which means if it is found that errors from the wage 
equation are not correlated with the errors from the selection equation, then OLS estimates are not biased and it is legitimate to run two independent regressions: OLS for wages and Probit for selection. The correlation coefficient $\left(\rho_{\text {ue }}\right)$ can be either positive or negative. A negative coefficient means that some omitted variable in the wage equation affects the selection in an opposite direction to its effect on wages. In such a case (negative $\rho_{\text {ue }}$ and hence $\lambda$ ), the inverse Mills ratio will be significant and individuals who select agriculture will have lower average wages. The likelihood ratio test (LR) tests the hypothesis of independent equations $\left(\mathrm{H}_{0}: \rho_{\mathrm{ue}}=0\right)$, that is no selection bias. The results of the selection equation are reported in Table 2 (first-stage estimates). The sign of $\rho_{\mathrm{ue}}$ and hence $\lambda$ is negative. That implies that individuals who self-select into agriculture will have a negative impact on average wages. On the other hand, because wages for those in agriculture and other industries are observed, it would make sense to consider the issue as one of endogeneity and estimate the regression by instrumental variables (IV). We report the joint maximum likelihood estimation results since an alternative specification, which includes the linear and quadratic terms of tenure instead of the linear and quadratic term of age, results in a highly significant LR test.

Finally, we report the OLS and IV estimates of the wage equation using the independent variables in the selection equation (in addition to the wage equation regressors) as instruments for employed in agricultural dummy. An individual employed in agriculture will have the value of 1 and zero otherwise. Tables 3, 4, 5, and 6 report estimates of the OLS and IV estimates for the wage equation. The coefficient on agricultural industry dummy indicates that wages for workers employed in agriculture are 34 and 37 \% lower for non-

Table 3 OLS estimates of the wage equation (robust Se)

\begin{tabular}{|c|c|c|c|c|}
\hline \multirow[t]{2}{*}{$\overline{\text { Variable }^{a}}$} & \multicolumn{2}{|l|}{ Non-rural } & \multicolumn{2}{|l|}{ Rural } \\
\hline & Coeff. & $P$ value & Coeff. & $P$ value \\
\hline Schooling & 0.029 & 0.000 & 0.019 & 0.000 \\
\hline Age & 0.054 & 0.000 & 0.038 & 0.000 \\
\hline Age square & -0.001 & 0.000 & 0.000 & 0.000 \\
\hline Female & -0.304 & 0.000 & -0.387 & 0.000 \\
\hline Work in Israel & 0.710 & 0.000 & 0.587 & 0.000 \\
\hline \multicolumn{5}{|l|}{ Occupation dummies ${ }^{a}$} \\
\hline Legislators and senior administrators & 0.492 & 0.000 & 0.317 & 0.000 \\
\hline Professionals and clerks & 0.203 & 0.000 & 0.051 & 0.009 \\
\hline Services and shop sales & 0.009 & 0.570 & -0.122 & 0.000 \\
\hline Skilled agricultural and fishery workers & \multicolumn{2}{|l|}{ (Omitted) } & \multicolumn{2}{|l|}{ (Omitted) } \\
\hline Crafts' workers & 0.009 & 0.547 & 0.054 & 0.002 \\
\hline Plant and machine operators & -0.051 & 0.001 & -0.055 & 0.002 \\
\hline Elementary occupations & -0.070 & 0.000 & -0.091 & 0.000 \\
\hline Work in agriculture & -0.259 & 0.000 & -0.300 & 0.000 \\
\hline Constant & 2.478 & 0.000 & 3.457 & 0.000 \\
\hline N & \multicolumn{2}{|l|}{156,647} & \multicolumn{2}{|l|}{68,609} \\
\hline$R$-squared & \multicolumn{2}{|l|}{0.6805} & \multicolumn{2}{|l|}{0.6973} \\
\hline Mean VIF & \multicolumn{2}{|l|}{4.0} & \multicolumn{2}{|l|}{15.2} \\
\hline
\end{tabular}

${ }^{\mathrm{a}}$ Quarterly dummies and governorate dummies are not reported for brevity, and the set of instruments includes the wage plus selection equation variables. The VIF for the work in agriculture is 1.29 , for the skilled agricultural and fishery workers is omitted, and for the non-rural inhabitants. For the rural population, the VIF for the work in agriculture is 1.29 and for the skilled agricultural and fishery workers is omitted 
Table 4 IV estimates of the wage equation (robust Se)

\begin{tabular}{|c|c|c|c|c|}
\hline \multirow[t]{2}{*}{ Variable $^{a}$} & \multicolumn{2}{|l|}{ Non-rural } & \multicolumn{2}{|l|}{ Rural } \\
\hline & Coeff. & $P$ value & Coeff. & $P$ value \\
\hline Schooling & 0.028 & 0.000 & 0.017 & 0.000 \\
\hline Age & 0.050 & 0.000 & 0.037 & 0.000 \\
\hline Age square & 0.000 & 0.000 & 0.000 & 0.000 \\
\hline Female & -0.247 & 0.000 & -0.318 & 0.000 \\
\hline Work in Israel & 0.721 & 0.000 & 0.577 & 0.000 \\
\hline \multicolumn{5}{|l|}{ Occupation dummies $^{a}$} \\
\hline Legislators and senior administrators & 0.598 & 0.000 & 0.433 & 0.000 \\
\hline Professionals and clerks & 0.298 & 0.000 & 0.147 & 0.000 \\
\hline Services and shop sales & 0.106 & 0.000 & 0.000 & 0.971 \\
\hline Skilled agricultural and fishery workers & 0.088 & 0.000 & 0.145 & 0.000 \\
\hline Crafts' workers & 0.116 & 0.000 & 0.177 & 0.000 \\
\hline Plant and machine operators & 0.022 & 0.000 & 0.037 & 0.000 \\
\hline Elementary occupations & \multicolumn{2}{|l|}{ (omitted) } & \multicolumn{2}{|l|}{ (omitted) } \\
\hline Work in agriculture & -0.344 & 0.000 & -0.372 & 0.000 \\
\hline Constant & 2.606 & 0.000 & 3.163 & 0.000 \\
\hline N & \multicolumn{2}{|l|}{114,059} & \multicolumn{2}{|l|}{48,115} \\
\hline$R$-squared & \multicolumn{2}{|l|}{0.689} & \multicolumn{2}{|l|}{0.7076} \\
\hline
\end{tabular}

${ }^{a}$ Quarterly dummies and governorate dummies are not reported for brevity, and the set of instruments includes the wage plus selection equation variables

rural and rural areas (Table 4). The OLS estimates are consistent with the IV estimates but smaller in magnitude. The effects of schooling, gender, and work in Israel premium are similar whether OLS or IV is used. ${ }^{24}$

Turning to non-linear specification of schooling, we find that the models' predictive ability improves marginally. Tables 5 and 6 report a non-linear specification of the schooling variable and use tenure in the last job instead of potential experience. We find an increase in $R^{2}$ and significant "degree effect." Results show that workers with graduate degrees earn as much as $74 \%$ more than illiterates for non-rural areas, but $60 \%$ in rural areas (Table 6). Thus, returns to schooling are lower in rural areas suggesting that the proportion of employment in Israel (typically lower skills and higher wages) may be contributing to this phenomenon.

Wooldridge's (1995) score test of exogeneity of employment in agriculture is rejected at high levels ( $5 \%$ or lower) giving support to the endogeneity of employment in agriculture. OLS results in Tables 3 and 5 support the argument that employment in agriculture contributes to decreasing wages; however, the magnitude is lower owing possibly to endogeneity bias.

\section{Conclusions}

Aiming to identify the role of agricultural and non-agricultural employment in improving the well-being of the Palestinian rural population through their impact on wages, this paper investigates the determinants of wages for rural and non-rural areas. The development literature postulates that the development process is likely to be associated with rural urban migration as a result of improvement in worker productivity in agriculture. At the same time, agglomeration effects will tend to make urban-rural wage 
Table 5 OLS estimates of the wage equation (robust Se, non-linear schooling)

\begin{tabular}{|c|c|c|c|c|}
\hline \multirow[t]{2}{*}{ Variable $^{a}$} & \multicolumn{2}{|l|}{ Non-rural } & \multicolumn{2}{|l|}{ Rural } \\
\hline & Coeff. & $P$ value & Coeff. & $P$ value \\
\hline Illiterate & (Omitted) & & (Omitted) & \\
\hline Primary & 0.133 & 0.000 & 0.107 & 0.000 \\
\hline Secondary and lower diploma & 0.246 & 0.000 & 0.172 & 0.000 \\
\hline College and higher diploma & 0.460 & 0.000 & 0.370 & 0.000 \\
\hline Graduate & 0.784 & 0.000 & 0.602 & 0.000 \\
\hline Tenure & 0.002 & 0.000 & 0.002 & 0.000 \\
\hline Tenure square & $-2.000 \mathrm{E}-07$ & 0.000 & $-1.600 \mathrm{E}-07$ & 0.000 \\
\hline Female & -0.272 & 0.000 & -0.364 & 0.000 \\
\hline Work in Israel & 0.729 & 0.000 & 0.584 & 0.000 \\
\hline \multicolumn{5}{|l|}{ Occupation dummies ${ }^{\mathrm{a}}$} \\
\hline Legislators and senior administrators & (Omitted) & & (Omitted) & \\
\hline Professionals and clerks & -0.243 & 0.000 & -0.231 & 0.000 \\
\hline Services and shop sales & -0.421 & 0.000 & -0.363 & 0.000 \\
\hline Skilled agricultural and fishery workers & -0.417 & 0.000 & -0.244 & 0.000 \\
\hline Crafts' workers & -0.436 & 0.000 & -0.191 & 0.000 \\
\hline Plant and machine operators & -0.407 & 0.000 & -0.265 & 0.000 \\
\hline Elementary occupations & -0.470 & 0.000 & -0.330 & 0.000 \\
\hline Work in agriculture & -0.286 & 0.000 & -0.312 & 0.000 \\
\hline Constant & 4.135 & 0.000 & 3.990 & 0.000 \\
\hline N & 160,445 & & 7066 & \\
\hline$R$-squared & 0.686 & & 0.704 & \\
\hline Mean VIF & 4.02 & & 5.2 & \\
\hline
\end{tabular}

${ }^{a}$ Quarterly dummies and governorate dummies are not reported for brevity, and the set of instruments includes the wage plus selection equation variables. The VIF for the work in agriculture is 1.29, for the skilled agricultural and fishery workers is 1.37, and for the non-rural inhabitants. For the rural population, the VIF for the work in agriculture is 1.69 and for the skilled agricultural and fishery workers is 1.72

gap diminish due to the increased labor supply from rural areas. Our study hypothesizes that proximity to the Israeli labor market tends to raise rural wages due to the higher share of employment in Israel for the rural areas. However, employment in Israel and the settlements may be a cause for concern with respect to rural-urban wage differential and the impact on unemployment resulting from closures. Given the lower average years of schooling for rural workers and the lower wage in agriculture rural wages may decline if employment in Israel continues to diminish in importance for rural workers. The political stalemate in the peace process (and Israeli policy) will deter many Palestinians from seeking employment in Israel in the long run.

The findings of regression analysis lead us to the following: first, the employment in agriculture lowers average wages by a range from 26 to $34 \%$ for the non-rural population and $30-37 \%$ for rural population. Meanwhile, Israeli closures tend to raise the probability of selecting agriculture as a sector for employment. This implies that special educational programs be designed to improve the well-being of farm workers especially rural areas.

Second, the return to education is lower for rural workers than for non-rural ones, coupled with the information that average years of schooling is lower for rural workers and that the returns show signs of being higher at higher education levels (convexity); 
Table 6 IV estimates of the wage equation (robust Se, non-linear schooling)

\begin{tabular}{|c|c|c|c|c|}
\hline \multirow[t]{2}{*}{ Variable $^{a}$} & \multicolumn{2}{|l|}{ Non-rural } & \multicolumn{2}{|l|}{ Rural } \\
\hline & Coeff. & $P$ value & Coeff. & $P$ value \\
\hline Illiterate & (Omitted) & & (Omitted) & \\
\hline Primary & 0.121 & 0.000 & 0.119 & 0.000 \\
\hline Secondary and lower diploma & 0.217 & 0.000 & 0.174 & 0.000 \\
\hline College and higher diploma & 0.416 & 0.000 & 0.360 & 0.000 \\
\hline Graduate & 0.739 & 0.000 & 0.598 & 0.000 \\
\hline Tenure & 0.002 & 0.000 & 0.001 & 0.000 \\
\hline Tenure square & $-1.710 \mathrm{E}-07$ & 0.000 & $-1.370 \mathrm{E}-07$ & 0.000 \\
\hline Female & -0.229 & 0.000 & -0.305 & 0.000 \\
\hline Work in Israel & 0.734 & 0.000 & 0.576 & 0.000 \\
\hline \multicolumn{5}{|l|}{ Occupation dummies $^{a}$} \\
\hline Legislators and senior administrators & 0.507 & 0.000 & 0.351 & 0.000 \\
\hline Professionals and clerks & 0.251 & 0.000 & 0.103 & 0.000 \\
\hline Services and shop sales & 0.080 & 0.000 & -0.003 & 0.000 \\
\hline Skilled agricultural and fishery workers & 0.055 & 0.002 & 0.134 & 0.662 \\
\hline Crafts' workers & 0.079 & 0.000 & 0.175 & 0.000 \\
\hline Plant and machine operators & 0.064 & 0.000 & 0.073 & 0.000 \\
\hline Elementary occupations & (Omitted) & & (Omitted) & 0.000 \\
\hline Work in agriculture & -0.331 & 0.000 & -0.352 & 0.000 \\
\hline Constant & 3.680 & 0.000 & 3.731 & 0.000 \\
\hline N & 116,938 & & 49,596 & \\
\hline$R$-squared & 0.700 & & 0.715 & \\
\hline
\end{tabular}

${ }^{\mathrm{a}}$ Quarterly dummies and governorate dummies are not reported for brevity, and the set of instruments includes the wage plus selection equation variables

then, rural areas require policies which encourage higher education to lower the gap with non-rural areas.

Third, geographic disparity in wages between the West Bank and Gaza has strong implications for ending the political divide between the two areas that exists since Hamas took over Gaza in 2008 and Fatah remains in control of the West Bank. If the governments in both areas agree on securing a safe passage between the West Bank and Gaza, ${ }^{25}$ labor market integration would mean the wage gap that exists would be lower as low-wage workers will tend to migrate to higher wage regions.

Fourth, having a household head who works in agriculture is a highly significant factor in explaining the selection of agriculture as a sector of employment. Other factors that lead to a higher probability of selecting agriculture are household size, the 2006 period (following Hamas's control of the Palestinian Legislative Council elections), household wage income, and single individuals. Schooling significantly reduces the probability of selecting wage employment in agriculture. Thus, if schooling raises wages and lowers selection into agriculture, the policy implication is to increase the schooling of rural population.

Fifth, the gender wage gap is higher in non-rural areas. The literature review shows that part of this gap is unexplained by endowments (possibly a big share of the gap); thus, a thorough investigation is needed to understand the source of this gap, hence contributing to its reduction. 
In light of the preceding, policies aimed at increasing productivity of workers in agriculture are required to reduce the wage gap between rural and non-rural workers particularly for those who choose agricultural employment. Employment in Israel and the settlement should not be a long-term strategy for Palestinian workers despite its positive impact on rural wages; its long-run impact on schooling might be devastating for it lowers the return on education making it an un-attractive investment. Also, since periods of political unrest and conflict (characterized by closures and access restrictions) lead to labor market disruptions, the PA may consider lower dependence on the Israeli labor market for employment in favor of agricultural sector employment. The evidence on higher return for higher education (convexity of returns to education) implies that expenditure on higher education is an attractive option for both rural and non-rural areas.

\section{Endnotes}

${ }^{1}$ The 1993 Oslo peace accords between the PLO and Israel resulted in the division of the occupied West Bank and the Gaza Strip into three distinct security areas. Area A is mostly urban and refugee camps and falls under Palestinian security control. Area B is a joint security control and mostly townships. Area $\mathrm{C}$ is under Israeli security control and is mostly villages and vast unpopulated land.

${ }^{2} \mathrm{~A}$ search in jstore and Google on the differential impact of employment in agriculture on rural and urban localities resulted in many hits of the agricultural/non-agricultural wage gap or rural-urban wage gap; however, none of the papers directly addressed this issue.

${ }^{3}$ The constant of the wage equation is slightly higher for rural areas in most regressions.

${ }^{4}$ The impact of the Israeli policy of switching reliance on foreign guest workers instead of Palestinian workers on Palestinian employment and wages is analyzed in Aranki and Daoud (2010). The authors show that just over $40 \%$ of the Gazan labor force and about $32 \%$ of West Bank labor force were employed in Israel in the mid-1980s. These figures dropped to roughly 5 and $10 \%$ for Gaza and the West Bank, respectively.

${ }^{5}$ It was not until 2008 that the PA started limiting public employment in the face of mounting budget deficits and criticism by the academic community of the composition of current and capital expenditures.

${ }^{6}$ These results pertain to Indian workers with less than primary education.

${ }^{7}$ The most commonly addressed issue in the definition of subsistence agriculture is the small share of output destined to the market. Put another way, subsistence agriculture is predominantly characterized by own consumption (Heidhues and Brüntrup 2003). They argue that although it is seen as synonymous with backwardness and inefficiency, people choose this type of work as the only means for family survival. They argue from a theoretical perspective that low wages, high unemployment, and irregularity of payments are responsible for the choice into subsistence farming.

${ }^{8}$ Petrick and Tyran (2003) provide a theoretical framework that links subsistence agriculture to the process of development and structural change. The first incentive for subsistence farmers to commercialize is the existence of higher profits for commercial farmers. Second, structural change implies that subsistence farmers may rent their land to commercial ones, thus losing the security of own consumption. Third, commercial farming is positively correlated with higher investment and efficiency enhancement 
activities; thus, one would expect a lower capital stock the more subsistence farming there is. These, among other factors, lead the authors to the hypothesis of the demise of subsistence agriculture. This, although, in the long run, low labor productivity, low job creation, persistence of subsistence, and imperfect capital markets may slow down the process.

${ }^{9}$ Yellen (1984) and Ezeala-Harrison (2005) provide a good review of efficiency wage models.

${ }^{10}$ Angrist's sample was based on Israel's Central Bureau of Statistics of Palestinian males ages 18-64.

${ }^{11}$ This term refers to the restriction on Palestinian workers from reaching the Israeli labor market.

${ }^{12}$ For each quarter, household visits began in the first week of the first month in that quarter and continued for 13 weeks.

${ }^{13} 2006$ was a year in which government activities came to almost a complete stop after Hamas won the elections with a clear majority taking control of the Palestinian Legislative Council; consequently, the donor countries halted their donations. On the other hand, 2010 was a year of good economic performance.

${ }^{14}$ The smaller area of Gaza and easier movement between governorates can explain this phenomenon. So in Gaza, it is more of commuting than migration.

${ }^{15}$ The set of explanatory variables includes schooling, gender, experience, industry, occupation, marital status, geographic dummies, and quarter dummies.

${ }^{16}$ Unpaid family members are a prime example.

${ }^{17}$ Employment in agriculture is included as an explanatory variable in Tables 5 and 6 to show the effect of being employed in agriculture on wages for each type of locality.

${ }^{18}$ Self-selection results in biased estimates for the wage equation; the sign of the bias may be upward or downward. See Tansel and Daoud (2011) for more details.

${ }^{19}$ See Daoud and Sadeq (2012) for more on the determinants of returns to schooling in Palestine.

${ }^{20}$ The age-schooling interactive term was dropped due to its insignificance.

${ }^{21}$ The settlements are scattered mostly over the occupied West Bank outside the green line separating the West Bank from "Israel."

${ }^{22}$ The Palestinian authority (through donor funding) started programs to support agriculture; the programs include rural roads, irrigation wells, and giving trees to improve and cultivate the land. More support is needed in the area of commercial farming especially in areas were land confiscation for settlement activity is highly probable.

${ }^{23}$ This expression excludes widowed, divorced, married, etc.

${ }^{24}$ Reporting of the variance inflation factor (VIF) at the bottom of Tables 3 and 5 was motivated by the possibility of high correlation between skilled agricultural and fishery workers and work in agriculture. These figures turned out to be acceptable (since the values are less than 4 which is used as a role of thump). But the mean VIF for all regressors turned very high for rural regressions owing district-specific correlations. In all cases, this would be worrisome if the variables were individually insignificant, but collectively significant which is not the case here.

${ }^{25}$ It is obvious that this is not a Palestinian decision; Israel is the one who holds the keys to this issue. While it is necessary that the Palestinians agree on ending the political division, Israel has a vested interest in keeping the status quo. 


\section{Acknowledgements}

We are indebted to the research support of Mr. Mohammad Hittawy who provided data and research support, to the reviewers of the ERF/GDN who provided comments on the earlier drafts of the paper, and finally to the anonymous referees and the editor of this journal who made invaluable suggestions to improve the paper.

Responsible editor: Hartmut F. Lehmann

\section{Funding}

This paper was funded by a generous grant from Global Development Network (GDN) and Economic Research Forum (ERF) who also provided the initial review of the paper and provided the very helpful comments in improving the quality of the paper.

\section{Competing interests}

The IZA Journal of Labor \& Development is committed to the IZA Guiding Principles of Research Integrity. The authors declare that they have observed these principles.

\section{Author details}

'Doha Institute for Graduate Studies, Al Tarfa Street, Zone 70, PO Box 200592, Al-Daayen, Qatar. ${ }^{2}$ Department of Economics, College of Business and Economics, Birzeit University, P O Box 14, Birzeit, Palestine. ${ }^{3}$ College of Administrative Sciences and Informatics, Palestine Polytechnic University, Hebron, Palestine.

Received: 15 April 2016 Accepted: 8 October 2016

Published online: 28 November 2016

\section{References}

Ahmad I (1982) Wage determination in Bangladesh agriculture. Oxford Economic Papers, New Series 33(2):298-322 Angrist J (1995) The economic returns to schooling in the West Bank and Gaza Strip. Am Econ Rev 85(5):1065-1087 Angrist J (1996) Short run demand for Palestinian labor. J Labor Econ 14(3):425-453

Angrist J (1998) The Palestinian labor market: from Gulf war to autonomy. MIT, Department of Economics, working paper 98-5 Aranki T, Daoud Y (2010) Competition, substitution, or discretion: an analysis of Palestinian and foreign guest workers in the Israeli labor market. Journal of Population Economics 23:1275-1300

Becker GS (1964) Human capital: a theoretical and empirical analysis. National Bureau of Economic Research, New York

Bliss C, Stern J (1976) Economic aspects of the connection between productivity and consumption. University of Essex, Discussion Paper No. 67

Caselli F, Coleman J (2001) The U.S. structural transformation and regional convergence: a reinterpretation. J Polit Econ 109(3):584-616

Combes PP, Duranton G, Gobillon L (2008) Spatial wage disparities: sorting matters! Forthcoming: Journal of Urban Economics. doi:10.1016/j.jue.2007.04.004

Daoud Y (2005) Gender gap in returns to schooling in Palestine. Econ Educ Rev 24(6):633-649

Daoud Y, Sadeq T (2012) Returns to schooling for Palestinian men and women: trends and determinants, Palestine Economic Policy Research Institute (MAS). Available in Arabic at http://www.palestineeconomy.ps/files/server/ 20151705132848-2.pdf.

Daoud Y, Shanti R (2012) Wage differentials and employment sector choice for Palestinian men and women: an empirical assessment. Munich Personal RePEc Archive, MPRA Paper No. 39782

Ezeala-Harrison F (2005) Two-tier wage systems in rural agriculture: evidence from Indonesian micro data. Southwestern Economic Review 32(1):13-24

Fallah B, Daoud Y (2015) Wage differential and economic restriction: evidence from the occupied Palestinian territories, Economics of Peace and Security Journal, Vol. 10, No. 1:13-22

Gollin D, Lagakos D, Waugh M (2014) The agricultural productivity gap. Q J Econ 129(2):939-993

Hazan M, Zoabi H (2011) Sons or daughters? Endogenous sex preferences and the reversal of the gender educational gap. The Pinhas Sapir Center for Development, Tel Aviv University

Heckman J (1976) The common structure of statistical models of truncation, sample selection, and limited dependent variables and a simple estimator for such models. The Annals of Economic and Social Measurement 5:931-959

Heidhues F, Brüntrup M (2003) Subsistence agriculture in development: its role in processes of structural change. In: Abele S, Frohberg K (eds) Subsistence Agriculture in Central and Eastern Europe: How to Break the Vicious Circle? Institut für Agrarentwicklung in Mittel- und Osteuropa (IAMO)

Hertz T, Winters P, de la OAP, Quiñones E, Davis B, Zezza A (2008) Wage inequality in international perspective: effects of location, sector, and gender. ESA Working Paper No. 08-08

Hnatkovska V, Lahiri A (2013) Structural transformation and the rural-urban divide, University of British Columbia Kim S (1990) Labor heterogeneity, wage bargaining, and agglomeration economies. J Urban Econ 28:160-177

Lagakos D, Waugh M (2009) Specialization, economic development and aggregate productivity differences., Available at https://economicdynamics.org/meetpapers/2009/paper_1248.pdf

Lagakos D, Waugh M (2013) Selection, agriculture, and cross-country productivity differences. Am Econ Rev 103(2):948-980

Lagakos D, Mobarak M, Waugh M (2016) Urban-rural wage gaps in developing countries: spatial misallocation or efficient sorting?, available at https://www.economicdynamics.org/meetpapers/2016/paper_1032.pdf

Leibenstein H (1957) The theory of underemployment in backward economies. J Polit Econ 65:91-103

Lewis W (1954) Economic development with unlimited supplies of labor, Manchester School, May 1954

Maluccio J (1998) Endogeneity of schooling in the wage function: evidence from the rural Philippines, FCND discussion paper no. 54

Mansour $\mathrm{H}$ (2010) The effects of labor supply shocks on labor market outcomes: evidence from the Israeli-Palestinian conflict. Labor Economics 17:930-939 
McCormick B, Wahba J (2005) Why do the young and educated in LDCs concentrate in large cities? Evidence from migration data. Economica New Series 72(285):39-67

Miaari S (2009) The public-private wage differential in the West Bank and Gaza Strip before and during the second Intifada. EUI working papers, MWP 2009/13, MAX Weber Program

Mincer J (1974) Schooling, experience, and earnings. National Bureau of Economic Research. Columbia University Press, New York

Moretti E, Perloff J (2002) Efficiency wages, deferred payments, and direct incentives in agriculture. Am J Agric Econ 84:1144-1155

Munshi K, Rosenzweig M (2016) Networks and misallocation: insurance, migration, and the rural-urban wage gap. Am Econ Rev 106(1):46-98. doi:10.1257/aer.20131365

Petrick M, Tyran E (2003) Developmental perspectives of subsistence farms in southeastern Poland: social buffer stock or commercial agriculture. In: Abele S, Frohberg K (eds) Subsistence Agriculture in Central and Eastern Europe: How to Break the Vicious Circle? Institut für Agrarentwicklung in Mittel- und Osteuropa (IAMO)

Sayre E (2001) Labor demand and the wage gap: evidence from the West Bank and Gaza Strip. Contemp Econ Policy 19(2):213-224

Sayre E, Miller K (2004) Wage compression and returns to schooling for Palestinian men from 1995 to 2001. Agnes Scott College, Decatur

Stiglitz J (1974) Wage determination and unemployment in L.D.C.'s: the labor turnover model. Q J Econ 88:194-227

Tansel A, Daoud Y (2011) Comparative essay on returns to education in Palestine and Turkey. Turkish Economic Association, discussion paper 2011/7

Winters P, de la OAP, Quiñones E, Hertz T, Davis B, Zezza A, Covarrubias K, Carletto G, Stamoulis K (2008) Rural wage employment and household livelihood strategies: a multicountry analysis. FAO, ESA Working paper

Wooldridge JM (1995) Score diagnostics for linear models estimated by two stage least squares. In: Maddala GS, Phillips PCB, Srinivasan TN (eds) Advances in econometrics and quantitative economics: essays in honor of Professor C. R. Rao. Blackwell, Oxford, pp 66-87

Yashiv E (2008) Positive or negative? Migrant workers 'self selection revised. Tel Aviv University mimeo

Yellen J (1984) Efficiency wage models of unemployment, The American Economic Review, 74(2), Papers and proceedings of the ninety-sixth annual meeting of the American Economic Association (May, 1984): 200-205

\section{Submit your manuscript to a SpringerOpen ${ }^{\circ}$ journal and benefit from:}

- Convenient online submission

- Rigorous peer review

- Immediate publication on acceptance

- Open access: articles freely available online

- High visibility within the field

- Retaining the copyright to your article 